February - 2021

\title{
Empirical Analysis of Return to Distance Higher Education in Different Disciplines
}

Fengliang Li and Liang Wang

Tsinghua University

\begin{abstract}
Few empirical studies have analyzed the return to distance higher education in different academic disciplines. This study used quantitative methods, data from a nationwide survey, and Mincerian earnings function to analyze the return to distance higher education among different disciplines in China's labor market. Results were compared with the return to face-to-face higher education and showed that the returns to face-to-face higher education were higher than those to distance higher education. Returns to the disciplines of economics and management were at a high level in both faceto-face and distance education; returns to the disciplines of literature, as well as education and law, were at a low level in both face-to-face and distance education. The returns to the disciplines of science and engineering were higher in face-to-face education than in distance education. This paper proposes several recommendations. Adults who do not have higher education degrees should invest in distance higher education to obtain considerable monetary returns, particularly in the disciplines with higher returns such as management and economics. China's distance education institutions should improve the quality of teaching in science and engineering education and find ways to provide high-quality experimental teaching practices. At the same time, they should scale back on instruction of literature, as well as education and law.
\end{abstract}

Keywords: distance education, face-to-face education, disciplines, return to education 


\section{Introduction}

With the rise of massive open online courses (MOOCs), distance higher education has once again attracted attention. Distance education can offer learning on a large scale, worldwide. There are three ways for learners in China ${ }^{1}$ to get junior college or undergraduate degrees: full time study in colleges and universities; adult schools; online education. According to the data of National Bureau of Statistics of China (2018), in 2018, the total number of Chinese undergraduate and junior college graduates is $11,659,684$, of which the total number of undergraduate and junior college graduates through online education is $1,949,189$. The number of online higher education graduates accounts for $16.72 \%$ of the total higher education graduates. A large proportion of adult education is also conducted through different forms of distance learning. Therefore, for China as a whole, the proportion of distance higher education graduates to all graduates is far more than $16.72 \%$.

In spite of such a large scale, few empirical studies have analyzed the return to distance higher education. For example, Hoxby (2014) compared the return to distance education with that of face-to-face education. Castaño-Muñoz et al. (2016) claimed theirs was the first empirical analysis of the return to distance higher education compared with face-to-face higher education. In fact, earlier, some Chinese scholars had empirically compared the return to distance education with face-to-face education in a Chinese journal (Li, Li, \& Zhang, 2015). Though there have been few empirical studies on the return to distance higher education, with the development of MOOCs, the field has attracted the attention of scholars from many countries. Even so, it seems there has been no empirical analysis comparing the return to distance higher education among different academic disciplines. This empirical study addressed this specific gap.

Since COVID-19, distance learning has been and will continue to be a popular learning method and channel. Distance higher education has been in greater demand. More and more learners want to know the benefits before they invest in distance higher education; this desire highlights the importance of the return to distance higher education among different disciplines. This paper used data collected from a large-scale survey in China to empirically analyze the return to distance higher education in different disciplines and make a comparative analysis with traditional face-to-face education to provide more empirical evidence in the field. This not only filled an academic gap, but also provided references and suggestions for distance higher education institutions and learners who want to invest in distance education.

\section{Literature Review}

\section{Return to Education Among Different Disciplines}

Since the emergence of the theory of human capital in the last century, there have been empirical studies on returns to education (Heckman et al., 2006). In addition to analysis of returns to different levels of schooling, studies have often compared the difference of returns among different groups, such as national differences, regional differences, gender differences, differences in public or private sector, and differences in various periods (Carnoy, 1995; Johnes et al., 2017; Psacharopoulos \& Patrinos, 2004).

Many scholars have also paid attention to differences in academic majors and disciplines in terms of educational returns in face-to-face education. As early as the 1970s, Koch (1972) measured the private internal rates of return for various undergraduate majors from 1968 to 1969 in the US. Koch found that 
several majors had the highest returns, such as mathematics (9.9\%), economics (9.7\%), and accounting (8.7\%). In the last century, many studies empirically analyzed differences in the income or starting salaries in different disciplines and found that the salaries of students in engineering and economics disciplines were higher than in other disciplines (Altonji, 1993; Angle \& Wissmann, 1981; Rumberger, 1984; Rumberger \& Thomas, 1993). But Bottomley and Dunworth (1974) found that because of the higher costs for science and technology disciplines, the individual returns to science and technology were lower than returns to social science.

In this new century, numerous empirical studies have continued to analyze the disciplinary differences of educational returns and learner's income (Saha \& Sensarma, 2011; Salas-Velasco, 2006; Thomas, 2000; Yang et al., 2011). Bell (2010) found that graduate students who majored in science, technology, engineering, and mathematics earned more than those who did not. Webber (2014) found that the average income of those majoring in engineering, computer science, and economics ranked higher than other students' income. Similarly, Abel and Deitz (2014) analyzed the return to different majors of American undergraduate education and found that the returns to engineering education were the highest (21\%), followed by math, computer science, and health (18\% for each), and followed by business (17\%). Lemieux (2014) also pointed out that returns to engineering, health, and business were higher than those of other disciplines. Saha and Sensarma (2011) analyzed the returns to education for male students in India and found that engineering and management disciplines had the highest returns at the undergraduate level.

Some empirical findings have differed. McRae (2019) found that business majors had the highest expected return, while the return to engineering majors was the lowest. Wu and Tang (2020) found that business, science, and engineering had the lowest educational returns, while humanities and social sciences had higher returns. Mertens and Röbken (2013) found that the returns to science and business disciplines were higher, while the returns to engineering were negative at the master level. Mertens and Röbken also analyzed the disciplinary differences of return to doctoral education and found that doctorates in economics and law had the highest returns (13.76\%), followed by $9.4 \%$ for social science, and $7.0 \%$ for engineering. It appears that disciplines and majors with the highest educational returns produce different results at various education levels.

There has also been some analyzing return in relation to gender differences in different disciplines. Glocker and Storck (2014) measured, by gender, the returns to different disciplines in three types of higher education institutions in Germany. They found that for male students in the universities of applied science, the returns to enterprise engineering, business, and chemical engineering were the highest, while for female students, the returns to computer science, and business were the highest. They also found that for male students in university, the returns to medicine, business, computer science, and enterprise engineering were the highest, while for female university students, the returns to medicine, dentistry, and business were the highest. For male students in vocational education, the returns to accounting, financial insurance, and computer science were the highest, while for female students, English, financial insurance, and marketing had the highest returns to education.

According to the existing studies, the returns to different disciplines have varied among different countries and time periods, and were also affected by gender, types of higher education institutions, and educational level. What kind of pattern is apparent in the disciplinary difference in the return to distance education? 


\section{Return to Distance Education}

In the literature, compared with studies on the return to face-to-face education, the studies on the return to distance education were limited. Woodley and Simpson (2001) investigated students in UK open universities and found that although they were adult learners, these students could still obtain a considerable return to part-time study. Carnoy et al. (2012) explored the return to distance higher education in an open university in Spain. They found that the two-year second-cycle degree distance education program brought positive returns for learners while the three-year first-cycle degree did not bring learners the corresponding returns. Castaño-Muñoz et al. (2016) continued their analysis in this Spanish open university and came to the conclusion that distance education would improve learners' income. Furthermore, those who entered university at a younger age and with no income before enrolling would get higher returns. Li, Li, and Zhang G (2015) also found that distance learners had considerable returns, which were even greater for female and rural learners. Li (2018) found that in China, with the expansion of face-to-face and distance higher education, the returns to both distance higher education and face-to-face higher education were in decline, and the returns to distance higher education were lower than those to face-to-face higher education. Even so, distance higher education could still bring considerable returns to learners, though not all empirical studies supported the notion that distance education could bring positive returns. For instance, Hulten (2018) found that learners' costs for distance higher education outweighed the returns because the benefits of distance education were low.

There are few empirical studies on the return to distance education and even fewer empirical studies comparing the return to distance education in different majors or disciplines. Carnoy et al. (2012) found that in Spain, the distance learners who studied enterprise management, marketing and IT engineering had higher income, with females earning more than males.

\section{Literature Review in Summary}

Although there have been many studies of disciplinary differences in the returns to face-to-face education, and there have been few studies of the returns to distance education, and no empirical studies of disciplinary differences in the returns to distance education. Therefore, this study explored the returns to education among different disciplines and compared them in the context of face-to-face as well as distance higher education. This study used large-scale and representative survey data of adults to empirically analyze the effect of disciplinary differences on the returns to distance education in China's labor market, and so has addressed the paucity of empirical studies on returns to distance education.

\section{Research Design and Data}

\section{Theoretical Framework}

According to human capital theory, individual income is positive related to human capital accumulated by education (Gillies, 2017). If with the same educational level, the same amount of human capital should be accumulated, then individual income should not differ significantly between a distance and a face-to-face learner. However, from the perspective of screening theory, education is an ability signal for employers, whereby employers screen potential employees by education (Cooper \& Davis, 2017). 
Distance education in China results in a lower ability signal, which suggests a form of education with lower quality. According to screening theory, the return to face-to-face education should be higher than that of distance education. This study used these two competing theories to compare the differences of return to different disciplines of distance education as well as face-to-face education.

According to human capital theory (Becker, 1964), human capital includes special human capital and general human capital, with the former type described as irreplaceable and more professional. Each type differs for different disciplines, which affect the return to education among different disciplines. Therefore, the differences of return indicate the emphasis on type of human capital among different disciplines. In exploring the return among different disciplines, this study examined two key aspects, by comparing the return:

- between face-to-face and distance education within the same discipline, and

- among different disciplines under the same form of education.

\section{Method}

Since is often used to explore the returns to education (Li, 2018; Glocker \& Storck, 2014; Mincer, 1974; Siphambe, 2000) this study used Mincerian earnings function to estimate the return to distance higher education. The standard Mincerian earnings function is:

$\operatorname{LnY}=a+b^{*} S+c^{*} E X+d^{*} E X 2+\varepsilon(1)$

$\mathrm{Y}$ is individual income; $\mathrm{LnY}$ is the logarithm of individual income; $\mathrm{S}$ represents the education year; $\mathrm{EX}$ represents work experience; EX2 represents the square of work experience; $\varepsilon$ is the residual item; a is an intercept; b, c, and d are all coefficients of variables; and b represents the increased rate of individual income to each marginal education year (i.e., Mincerian rate of return).

An important assumption is made in calculating the Mincerian returns to education, namely that education incurs opportunity cost only. However, for distance education, this assumption cannot stand. Many distance learners still hold down jobs when they study, so the opportunity cost for distance learners is low and coefficient $b$ can no longer be the rates of return to distance education. However, $b$ can reflect the return to distance education to some extent.

In addition, it should be noted that education is an endogenous variable. Academic discussion has long focused on the question of whether learners accumulate human capital through education and thus improve labor productivity (Schultz, 1961) and earn higher income, or if the individuals with better innate ability spontaneously choose to get a higher education level and thus get more income (Spence, 1973). This study did not explore the causal relationship between education and income, rather we simply used Mincerian earnings function to estimate the return to distance higher education in different disciplines, compared with face-to-face education. Nevertheless, it is also of great reference value to get the regression coefficient of distance education through Mincerian earnings function, which can then be compared with the relevant studies on face-to-face education (Psacharopoulos \& Patrinos, 2004; Saha \& Sensarma, 2011).

\section{Data}

This study used China Family Panel Studies (CFPS) data for empirical analysis. CFPS is a national largescale household survey data with good national representativeness (ISSS, Peking University, 2013). We 
used the adult data from CFPS 2010 which was a sample of 33,600 including information on education level, forms of education (i.e., distance vs. face-to-face), academic disciplines, and annual income.

To estimate the return to a certain education level by using Mincerian earnings function, the sub-sample of this education level and previous education level were put into the regression equation (Carnoy, 1995). To estimate the return to undergraduate education, the sub-samples of undergraduate and high school were put into the regression equation, and the coefficient of the years of education was then interpreted as the return to undergraduate education. Similarly, to estimate the return to junior college education, the sub-samples of junior college and high school were put into the regression equation. At present in China, only undergraduate and junior college students can obtain their degrees through distance education. Therefore, this study analyzed only the sub-samples of high school, junior college, and undergraduate. The total sample size was 6,821 , of which 3,911 cases were individuals who were not working.

Of the 2,910 cases that remained, 56 cases lacked information on educational form and 199 lacked information on income. After these cases were deleted, 2,655 valid cases remained. These 2,655 cases became the total sample used in the analysis, including 1,275 cases of high school, 392 cases of distance junior college, 393 cases of face-to-face junior college, 326 cases of distance undergraduate, and 244 cases of face-to-face undergraduate.

This study analyzed the disciplinary differences of the return to distance higher education. After having observed the disciplinary distributions of distance higher education cases, the sample sizes of three academic disciplines were large enough to be analyzed separately, namely literature, economics, and management. Since the sample sizes of science, engineering, education, and law were relatively small, this study combined these four disciplines. Science and engineering were grouped together, and education and law were combined into a second category. In this way, the study analyzed the returns to these five different categories with 148 cases of literature, 245 cases of economics, 278 cases of management, 362 cases of science and engineering, and 222 cases of education and law.

Table 1 presents the simple descriptive statistics of the variables used in this study. It should be noted that CFPS 2010 did not include information on when individuals started working. There is no way to get accurate information on the working years for individuals in our sample. To address this, we subtracted a case's years of education from their age and then subtracted 6 ("age-years of education-6") to approximate number of working years (Romele, 2014).

\section{Table 1}

Descriptive Statistics for the Core Variables

\begin{tabular}{lcc}
\hline Variable & Mean & Standard deviation \\
\hline Logarithm of income & 9.90 & 0.94 \\
Years of education & 13.78 & 1.75 \\
Working years & 12.26 & 6.99 \\
Square of working years & 199.23 & 185.15 \\
\hline
\end{tabular}

Note. $N=2655$. 


\section{The Results of Empirical Study}

First, this study compared the differences in returns to distance and face-to-face education. Table 2 shows the regression results of the standard Mincerian earnings function for undergraduate and junior college. For both distance and face-to-face education, the coefficients of the years of education were significantly positive. This shows that whether through distance or face-to-face, higher education can bring significant returns to both junior college and undergraduates. The results may reflect the function of education as human capital (Gillies, 2017; Schultz, 1961; Wang \& Sun, 2009) or as signal of ability (Cooper \& Davis, 2017; Spence, 1973; Wang \& Holton, 2005).

\section{Table 2}

Comparative Analysis of Return to Distance and Face-to-Face Education

\begin{tabular}{|c|c|c|c|c|}
\hline \multirow[t]{2}{*}{ Variable } & \multicolumn{2}{|c|}{ Distance education } & \multicolumn{2}{|c|}{ Face-to-face education } \\
\hline & Junior college & Undergraduate & Junior college & Undergraduate \\
\hline Years of education & $0.12^{* * *}(0.02)$ & $0.15^{* * *}(0.02)$ & $0.16^{* * *}(0.02)$ & $0.21^{* * *}(0.02)$ \\
\hline Working years & $0.11^{* * *}(0.01)$ & $0.12^{* * *}(0.01)$ & $0.14^{* * *}(0.01)$ & $0.13^{* * *}(0.01)$ \\
\hline Square of working years & $-0.003^{* * *}(0.0004)$ & $-0.004^{* * *}(0.0005)$ & $-0.004^{* * *}(0.0005)$ & $-0.004^{* * *}(0.0005)$ \\
\hline Constant & $7.44^{* * *}(0.22)$ & $7.02^{* * *}(0.21)$ & $6.88^{* * *}(0.26)$ & $6.27^{* * *}(0.22)$ \\
\hline Adj-R2 & 0.09 & 0.13 & 0.11 & 0.14 \\
\hline$n$ & 1635 & 1486 & 1638 & 1566 \\
\hline
\end{tabular}

Note. The dependent variable is the logarithm of income; the value in brackets is the standard error.

${ }^{* * *} p<0.01$

From Table 2, we see that for the same educational form, the returns to undergraduate were higher than those to junior college; for the same education level, the returns to face-to-face education were higher than those to distance education. Further data analysis indicated the differences summarized in Table 2 to be statistically significant. The returns to undergraduate were higher than those to junior college, which is consistent with the existing empirical findings on the return to education in China (Chen et al., 2003; Ding et al., 2012). The returns to distance education were lower than those to face-to-face education, also consistent with the empirical studies on China's labor market (Li, L, \& Zhang, 2015; Li, 2018). There are many explanations for why the returns to distance education are lower than those to face-to-face education, including the (a) lower signal value of distance education, (b) lower quality of distance education, and (c) lower opportunity cost of distance education (Castaño-Muñoz et al., 2016; Hoxby, 2014; Li, 2017; Stella \& Gnanam, 2004).

However, this study did not focus on the reasons why the return to distance education was lower. Rather, we compared differences in the returns to distance higher education by academic discipline. Table 3 
shows the regression results for the disciplines of literature, economics, and management by educational level and form (i.e., distance and face-to-face). Table 4 shows the regression results of science and engineering, as well as education and law, by educational level and form. 
Table 3

Returns to Distance Education and Face-to-Face Education in Literature, Economics, and Management

\begin{tabular}{|c|c|c|c|c|c|c|c|c|c|c|c|c|}
\hline \multirow[t]{4}{*}{ Variable } & \multicolumn{4}{|c|}{ Literature } & \multicolumn{4}{|c|}{ Economics } & \multicolumn{4}{|c|}{ Management } \\
\hline & \multicolumn{2}{|c|}{ Distance } & \multicolumn{2}{|c|}{ Face-to-face } & \multicolumn{2}{|c|}{ Distance } & \multicolumn{2}{|c|}{ Face-to-face } & \multicolumn{2}{|c|}{ Distance } & \multicolumn{2}{|c|}{ Face-to-face } \\
\hline & Junior & Undergrad & Junior & Undergrad & Junior & Undergrad & Junior & Undergrad & Junior & Undergrad & Junior & Undergrad \\
\hline & college & & college & & college & & college & & college & & college & \\
\hline Years of & $0.14^{* *}$ & $0.14^{* * *}$ & $0.18^{* * *}$ & $0.15^{* * *}$ & $0.16^{* *}$ & $0.16^{* * *}$ & $0.18^{* * *}$ & $0.27^{* * *}$ & $0.15^{* * *}$ & $0.21^{* * *}$ & $0.16^{* * *}$ & $0.18^{* * *}$ \\
\hline education & (0.07) & (0.04) & (0.05) & $(0.04)$ & (0.03) & (0.04) & (0.04) & (0.04) & (0.03) & (0.03) & $(0.04)$ & (0.04) \\
\hline Working & $0.12^{* * *}$ & $0.12^{* * *}$ & $0.12^{* * *}$ & $0.13^{* * *}$ & $0.12^{* * *}$ & $0.12^{* * *}$ & $0.12^{* * *}$ & $0.12^{* * *}$ & $0.12^{* * *}$ & $0.12^{* * *}$ & $0.13^{* * *}$ & $0.13^{* * *}$ \\
\hline years & $(0.02)$ & (0.01) & (0.01) & (o.01) & (o.01) & (o.01) & (0.01) & (0.02) & (o.01) & (o.01) & (o.01) & (o.01) \\
\hline Square of & $-0.004^{* * *}$ & $-0.004^{* * *}$ & $-0.004^{* * *}$ & $-0.004^{* * *}$ & $-0.004^{* * *}$ & $-0.004^{* * *}$ & $-0.004^{* * *}$ & $-0.004^{* * *}$ & $-0.004^{* * *}$ & $-0.004^{* * *}$ & $-0.004^{* * *}$ & $-0.004^{* * *}$ \\
\hline working & (0.0005) & (0.0005) & (0.0005) & (0.0005) & (0.0005) & (0.0005) & (0.0005) & (0.0005) & (0.0005) & (0.0005) & (0.0005) & (o.0005) \\
\hline \multicolumn{13}{|l|}{ years } \\
\hline \multirow[t]{2}{*}{ Constant } & $7.16^{* * *}$ & $7.19^{* * *}$ & $6.69^{* * *}$ & $6.95^{* * *}$ & $6.88^{* * *}$ & $6.91^{* * *}$ & $6.69^{* * *}$ & $5 \cdot 57^{* * *}$ & $7.08^{* * *}$ & $6.32^{* * *}$ & $6.92^{* * *}$ & $6.70^{* * *}$ \\
\hline & (o.83) & $(0.43)$ & (o.68) & $(0.45)$ & $(0.41)$ & $(0.48)$ & $(0.46)$ & $(0.47)$ & $(0.38)$ & $(0.41)$ & $(0.49)$ & $(0.48)$ \\
\hline Adj-R2 & 0.07 & 0.08 & 0.07 & 0.07 & 0.08 & 0.07 & 0.08 & 0.09 & 0.08 & 0.09 & 0.07 & 0.08 \\
\hline$n$ & 1262 & 1285 & 1275 & 1288 & 1329 & 1278 & 1315 & 1281 & 1353 & 1290 & 1309 & 1280 \\
\hline
\end{tabular}

Note. The dependent variable is the logarithm of income; the value in brackets is the standard error.

${ }^{* *} p<0.05 .{ }^{* * *} p<0.01$. 


\section{Table 4}

Returns to Distance Education and Face-to-Face Education in Science and Engineering, and Education and Law

\begin{tabular}{|c|c|c|c|c|c|c|c|c|}
\hline \multirow[t]{4}{*}{ Variable } & \multicolumn{4}{|c|}{ Science and engineering } & \multicolumn{4}{|c|}{ Education and law } \\
\hline & \multicolumn{2}{|c|}{ Distance } & \multicolumn{2}{|c|}{ Face-to-face } & \multicolumn{2}{|c|}{ Distance } & \multicolumn{2}{|c|}{ Face-to-face } \\
\hline & Junior & Undergrad & Junior & Undergrad & Junior & Undergrad & Junior & Undergrad \\
\hline & college & & college & & college & & college & \\
\hline \multirow[t]{2}{*}{ Years of education } & $0.12^{* *}$ & $0.15^{* * *}$ & $0.19^{* * *}$ & $0.26^{* * *}$ & 0.05 & $0.14^{* * *}$ & 0.04 & $0.18^{* * *}$ \\
\hline & $(0.04)$ & $(0.04)$ & $(0.03)$ & $(0.02)$ & $(0.04)$ & $(0.03)$ & $(0.05)$ & $(0.04)$ \\
\hline \multirow[t]{2}{*}{ Working years } & $0.12^{* * *}$ & $0.12^{* * *}$ & $0.13^{* * *}$ & $0.13^{* * *}$ & $0.12^{* * *}$ & $0.12^{* * *}$ & $0.13^{* * *}$ & $0.12^{* * *}$ \\
\hline & $(0.01)$ & (0.01) & (0.01) & $(0.01)$ & (0.01) & (0.01) & (0.01) & (0.01) \\
\hline Square of & $-0.004^{* * *}$ & $-0.004^{* * *}$ & $-0.004^{* * * *}$ & $-0.004^{* * *}$ & $-0.004^{* * *}$ & $-0.004^{* * *}$ & $-0.004^{* * *}$ & $-0.004^{* * *}$ \\
\hline working years & $(0.0005)$ & $(0.0005)$ & (0.0005) & $(0.0005)$ & $(0.0005)$ & $(0.0005)$ & $(0.0005)$ & $(0.0005)$ \\
\hline \multirow[t]{2}{*}{ Constant } & $7 \cdot 38^{* * *}$ & $7.06^{* * *}$ & $6.52^{* * *}$ & $5.69^{* * *}$ & $8.19^{* * *}$ & $7.16^{* * *}$ & $8.34^{* * *}$ & $6.72^{* * *}$ \\
\hline & $(0.47)$ & $(0.51)$ & $(0.38)$ & $(0.29)$ & $(0.48)$ & $(0.35)$ & (o.61) & $(0.45)$ \\
\hline Adj-R2 & 0.07 & 0.07 & 0.08 & 0.14 & 0.07 & 0.08 & 0.07 & 0.07 \\
\hline$n$ & 1307 & 1274 & 1376 & 1367 & 1305 & 1309 & 1284 & 1286 \\
\hline
\end{tabular}

Note. The dependent variable is the logarithm of income; the value in brackets is the standard error.

${ }^{* *} p<0.05 .{ }^{* * *} p<0.01$. 
First, the returns to all disciplines in distance junior college were significant, except for the category of education and law. The coefficients were, listed in order: economics > management $>$ literature $>$ science and engineering $>$ education and law, indicating that the returns of economics and management were higher than those to other disciplines for distance junior college students.

Second, the returns to all disciplines in distance undergraduate education were significantly positive, and the coefficients were, listed in order: management > economics $>$ science and engineering > education and law = literature. For distance undergraduate students, the educational returns of management and economics were the highest. For management disciplines, the return to distance undergraduate was even higher than that to face-to-face undergraduate.

Third, the returns to all disciplines in face-to-face junior college education were significant, except for that of education and law. The coefficients were, listed in order: science and engineering $>$ economics $=$ literature $>$ management $>$ education and law.

Fourth, the returns to all disciplines in face-to-face undergraduate education were significantly positive. The coefficients were, listed in order: economics $>$ science and engineering $>$ management $=$ education and law > literature.

\section{Discussion}

Our empirical results highlight several findings. First, economics, as well as science and engineering, had the highest returns to face-to-face education, in line with many existing studies (Abel \& Deitz, 2014; Del Rossi \& Hersch, 2008; Webber, 2014). This is probably due to the higher relative returns of those majors that focus on skills of quantitative analysis (Abel \& Deitz, 2014).

Second, the returns to distance junior college education and distance undergraduate education in economics and management were the highest. Students who choose economics and management in distance education will see higher education returns. With the rapid development of China's economy and the great demand for these disciplines in the labor market, graduates from economics and management are very competitive in their search for employment. This result was also consistent with the empirical findings of face-to-face education-the disciplines and majors related to business and economics had higher returns (Altonji, 1993; Angle \& Wissmann, 1981; Del Rossi \& Hersch, 2008; Webber, 2014).

Third, whether face-to-face or distance education, the returns to literature, as well as education and law, were low. On the one hand, this indicated that at the junior college or undergraduate level, the degree of relationship between market-demand skills and the learned knowledge through literature, as well as education and law, was small. On the other hand, this may also be related to the rapid increase in the number of graduates in these disciplines. With the rapid development of China's economy and society, labor market demand for literature, as well as education and law, has risen to the level of professional master's degree (Huang et al., 2017; Ministry of Education of the People's Republic of China, 2012).

Fourth, the returns to science and engineering in face-to-face education were relatively high, but in distance education, the returns to science and engineering were relatively low, inconsistent with most existing studies in face-to-face education. Why were the returns to science and engineering in distance education lower? One reason for this disparity may be the lack of laboratory experience in distance education for science and engineering; the specific human capital of science and engineering is difficult to effectively accumulate at a distance. 
The knowledge and skills learned in science and engineering are highly professional and classified as specific human capital (Becker, 1964). This kind of human capital, being valuable, scarce, irreplaceable, and non-imitative, can be used as the source of continuous competition for enterprises (Barney, 1991). Therefore, it is no wonder that in face-to-face education, compared with other disciplines such as management, literature, education, and law, the specific human capital of science and engineering is high and the returns to science and engineering very high as well. However, the accumulation of specific human capital of science and engineering requires the support of laboratories and experimental equipment. Laboratory work is central to science and engineering education (Feisel \& Rosa, 2005) and laboratory practice is very important for science and engineering students to improve their skills in the labor market (Striegel, 2001).

However, compared with face-to-face education, distance education is weaker at offering opportunities to learn through conducting experiments because of the separation of teachers and students, as well as the lack of classrooms, laboratories, equipment, and so on. For example, Soysal (2000) pointed out that an obvious disadvantage of distance education is the lack of equipment for doing experiments. Feisel and Rosa (2005) pointed out that it is difficult to provide laboratory experience in the distance education. Therefore, it may be difficult for the distance education of science and engineering to effectively accumulate specific human capital in the absence of teaching and learning via experiments. As a result, the returns to science and engineering in distance education were not only lower than faceto-face education in the same discipline, but also lower than economics and management in distance education.

Correspondingly, the study of economics and management must be closely linked with the labor market (Li, 2017). Most distance learners study part-time. They already have some work experience and continue to accumulate experience in the labor market as they study. Therefore, of all disciplines, distance learners in management and economics can gain the highest returns. Especially in management, the return to distance education was even higher than that to face-to-face education at undergraduate level.

\section{Conclusions}

With the development of MOOCs and the spread of the COVID-19 epidemic, the returns to distance higher education have gradually attracted the attention of scholars worldwide. In the future, distance education is likely to become a hot topic in higher education, economics of education, and other related fields. However, to date, studies have rarely involved comparative analysis of the return to distance education in different disciplines. This study analyzed the differences of returns to different forms (i.e., face-to-face and distance education), different levels (i.e., junior college and undergraduate education), and different disciplines, namely literature, economics, management, science and engineering, as well as education and law, using data with a good national representativeness. The study produced four important empirical findings.

First, the returns to face-to-face education were higher than that of distance education for most disciplines. We used screening theory to explain this finding-the reputation of distance education in China is relatively low, resulting in less than positive signals to the labor market. Despite this, the returns to distance higher education were still considerable for most disciplines. Therefore, as a whole, it is still a good choice to invest in distance education. 
Second, the returns to science and engineering education were higher in face-to-face education but lower in distance education. The study argues that the lack of laboratories and experiments, as well as the separation of teachers and students in the distance education, hinders the accumulation of specific human capital for science and engineering students.

Third, the returns to management and economics in distance education were the highest in all disciplines, and at the undergraduate level, the returns to distance management education were higher than those to face-to-face management education. These disciplines are closely related to the labor market. For distance education, most learners already have work experience and can accumulate the knowledge and skills related to economics and management through part-time study, thereby improving the return to distance education.

Fourth, no matter whether distance education or face-to-face education, the returns to literature, as well as education and law, were low. The study argues that due to the expansion of higher education in China, the requirements for the talents in these disciplines have been raised to the professional master level in China's labor market.

\section{Implications}

First, the purpose of the study was to explore the disciplinary differences of the return to distance education and compare them with face-to-face education. The comparison provides empirical findings to enhance our understanding of return to distance higher education.

Second, this study applied human capital theory and screening theory in distance education. We found that with the same educational level, the returns to face-to-face education were higher than to distance education. The reason may be that distance education produces a negative signal in the labor market because of its lower social reputation. This supports the notion that education plays a screening function and affects the return.

Third, the empirical results provide references for distance education learners and distance education institutions. For adult learners who hope to invest in distance higher education, they can consider the disciplines related to management and economics to bring higher returns. Distance education institutions should improve the teaching quality of science and engineering. In particular, China's distance education institutions can learn from the experience of international institutions to find highquality solutions suitable for teaching via laboratory experiments (Lemckert \& Florance, 2002; Pullen, 2001; Rudas \& Horváth, 2004; Soysal, 2000; Striegel, 2001). Furthermore, taking into account market demand, distance education institutions should appropriately reduce the scale of literature, education, and law so as to match market demand.

Finally, this paper hopes that more scholars will carry out research on the return to distance higher education, which has already become an important part of higher education system in many countries.

\section{Acknowledgements}

This article features research from "The Returns and Risks of Investment in Distance Higher Education" (project no.: 72074131), supported by the National Natural Science Foundation, China.

We would like to thank four anonymous reviewers for their useful comments and suggestions. 


\section{References}

Abel, J. R., \& Deitz, R. (2014). Do the benefits of college still outweigh the costs? Current Issues in Economics and Finance, 2O(3), 1-11. https://www.newyorkfed.org/medialibrary/media/research/current issues/ci20-3.pdf

Altonji, J. G. (1993). The demand for and return to education when education outcomes are uncertain. Journal of Labor Economics, 11(1), 48-83. https://doi.org/10.1086/298317

Angle, J., \& Wissmann, D. A. (1981). Gender, college major, and earnings. Sociology of Education, 54(1), 25-33. https://doi.org/10.2307/2112510

Barney, J. B. (1991). Firm resource and sustained competitive advantage. Journal of Management, 17(1), 99-120. https://doi.org/10.1177/014920639101700108

Becker, G. S. (1964). Human capital: A theoretical and empirical analysis, with special reference to education. Columbia University Press.

Bell, C. M. (2010). Graduate education attainment and salary: An examination of institutional type, major choice, gender, race/ethnicity, parental education and work experience differences (Publication No. ED519348) [Doctoral dissertation, Ohio University]. https://etd.ohiolink.edu/!etd.send_file?accession=ohiou1273520207\&disposition=inline

Bottomley, A., \& Dunworth, J. (1974). Rate of return analysis and economies of scale in higher education. Socio-Economic Planning Sciences, 8(5), 273-280. https://doi.org/10.1016/00380121(74)90012-3

Carnoy, M. (1995). Rates of return to education. In M. Carnoy (Ed.), International Encyclopedia of the Economics of Education (pp. 364-369). Elsevier Science Ltd.

Carnoy, M., Rabling, B. J., Castaño-Muñoz, J., Montoliu, J. M. D., \& Sancho-Vinuesa, T. (2012). Does on-line distance higher education pay off for adult learners? The case of the Open University of Catalonia. Higher Education Quarterly, 66(3), 248-271. https://doi.org/10.1111/j.14682273.2012.00520.x

Castaño-Muñoz, J., Carnoy, M., \& Duart, J. M. (2016). Estimating the economic payoff to virtual university education: A case study of the Open University of Catalonia. Higher Education, 72(1), 1-24. https://doi.org/10.1007/s10734-015-9935-1

Chen, X., Chen, L., \& Xia, C. (2003). Rates of return to schooling in urban China: Changes in the 1990s. Peking University Education Review, 2, 65-72.

https://www.cnki.net/kcms/doi/10.19355/j.cnki.1671-9468.2003.02.011.html

Cooper, J., \& Davis, L. (2017). Exploring comparative economic theories: Human capital formation theory vs. screening theory. Journal of Applied Business and Economics, 19(6). https://articlegateway.com/index.php/JABE/article/view/732

Del Rossi, A. F., \& Hersch, J. (2008). Double your major, double your return? Economics of Education Review, 27(4), 375-386. https://doi.org/10.1016/j.econedurev.2007.03.001

Ding, X., Yu, H., \& Yu, Q. (2012). Private returns to different education levels in urban China: 20022009. Peking University Education Review, 3, 73-84.

https://www.cnki.net/kcms/doi/10.19355/j.cnki.1671-9468.2012.03.008.html 
Feisel, L. D., \& Rosa, A. J. (2005). The role of the laboratory in undergraduate engineering education. Journal of Engineering Education, 94(1), 121-130. https://doi.org/10.1002/j.21689830.2005.tboo833.x

Gillies, D. (2017). Human capital theory in education. Encyclopedia of educational philosophy and theory (pp. 1-5). Springer. https://doi.org/10.1007/978-981-287-532-7_254-1

Glocker, D., \& Storck, J. (2014). Risks and returns to educational fields-A financial asset approach to vocational and academic education. Economics of Education Review, 42, 109-129. https://doi.org/10.1016/j.econedurev.2014.06.004

Heckman, J. J., Lochner, L. J., \& Todd, P. E. (2006). Earnings functions, rates of return and treatment effects: The Mincer equation and beyond. In E. A. Hanushek, S. J. Machin, \& L. Woessmann (Eds.), Handbook of the economics of education (pp. 307-458). Elsevier. https://doi.org/10.1016/S1574-0692(06)01007-5

Hoxby, C. M. (2014). The economics of online postsecondary education: MOOCs, nonselective education, and highly selective education. American Economic Review, 104(5), 528-533. http://dx.doi.org/10.1257/aer.104.5.528

Huang, B., Tang, J., \& Hao, T. (2017). The development of professional degree postgraduate education in China. China Higher Education, 2, 18-24.

Hulten, C. R. (2018). The Importance of Education and Skill Development for Economic Growth in the Information Era. In: Hulten C. R., \& Ramey, V. A. (Eds.), Education, skills, and technical change: Implications for future US GDP growth (pp.115-146). Chicago, USA: University of Chicago Press.

Johnes, G., Johnes, J., \& López-Torres, L. (2017). Human capital and returns to education. In G. Johnes, J. Johnes, T. Agasisti, \& L. López-Torres (Eds.), Handbook of contemporary education economics (pp. 1-20). Edward Elgar Publishing. https://www.elgaronline.com/view/edcoll/9781785369063/9781785369063.xml

Koch, J. V. (1972). Student choice of undergraduate major field of study and private internal rates of return. Industrial and Labor Relations Review, 26(1), 680-685.

http://dx.doi.org/10.1177/001979397202600106

ISSS, Peking University. (2013). Introduction of CFPS. http://www.isss.pku.edu.cn/cfps/en/index.htm?CSRFT=9OAW-DUVP-I5WW-JFGK-XEZHJRL2-S420-1OLY

Lemckert, C., \& Florance, J. (2002). Real-Time Internet mediated laboratory experiments for distance education students. British Journal of Educational Technology, 33(1), 99-102.

https://doi.org/10.1111/1467-8535.00243

Lemieux, T. (2014). Occupations, fields of study and returns to education. Canadian Journal of Economics/Revue canadienne d'économique, 47(4), 1047-1077. https://doi.org/10.1111/caje.12116

Li, D. (2017). The comparison of regional disparity of returns to education in China-An empirical study based on CHIP data [Unpublished master's thesis]. Dongbei University of Finance Economics. 
Li, F. L. (2017). The economics of distance education. In G. Johnes, J. Johnes T. Agasisti, \& J. LópezTorres (Eds.), Handbook of contemporary education economics (pp. 381-397). Edward Elgar Publishing.

Li, F. L. (2018). The expansion of higher education and the returns to distance education in china. International Review of Research in Open and Distributed Learning, 19(4), 242-256.

Li, F. L., Li, Y. Y., \& Zhang, S. G. (2015). The effect of distance higher education on the individual income: from the perspective of rural-urban difference and gender difference. $e$-Education Research, 2015(7), 49-54.

McRae, J. A. (2019). Estimating the financial return to education between fields of study. SURG Journal, 11. https://doi.org/10.21083/surg.v11io.5354

Mertens, A., \& Röbken, H. (2013). Does a doctoral degree pay off? An empirical analysis of rates of return of German doctorate holders. Higher Education, 66(2), 217-231. https://doi.org/10.1007/s10734-012-9600-X

Mincer, J. (1974). Schooling, experience and earnings. Columbia University Press.

Ministry of Education of the People's Republic of China. (2012). Some opinions of the Ministry of Education on how to comprehensively improve the quality of higher education. http://www.moe.gov.cn/srcsite/A08/s7056/201203/t20120316 146673.html

National Bureau of Statistics of China. (2018). Annual data (2018). https://data.stats.gov.cn/english/easyquery.htm?cn=Co1.

Psacharopoulos, G., \& Patrinos, H. A. (2004). Returns to investment in education: A further update. Education Economics, 12(2), 111-134. https://doi.org/10.1080/0964529042000239140

Pullen, J. M. (2001, February). Applicability of Internet video in distance education for engineering [Paper presentation]. Frontiers in Education Conference, Reno, USA. https://doi.org/10.1109/FIE.2001.963893

Rudas, J., \& Horváth, L. (2004). Course model based distance higher education of engineering modeling. WSEAS Transactions on Advances in Engineering Education, 1(1), 67-72.

Romele, L. (2014). Estimation of rates of return to investments in education in Latvia. Regional Formation and Development Studies, 11(3), 146-151. https://doi.org/10.15181/rfds.v11i3.623

Rumberger, R. (1984). The changing economic benefits of college graduates. Economics of Education Review, 3(1), 3-11. https://doi.org/10.1016/0272-7757(84)90003-7

Rumberger, R., \& Thomas, S. (1993). The economic returns to college quality, major, and performance: A multilevel analysis of recent graduates. Economics of Education Review, 12(1), 1-19. https://doi.org/10.1016/0272-7757(93)90040-N

Saha, B., \& Sensarma, R. (2011). Academic specialisation and returns to education: Evidence from India. Journal of Education and Work, 24(5), 501-520. https://dx.doi.org/10.1080/13639080.2011.573775

Salas-Velasco, M. (2006). Private returns to a university education: An instrumental variables approach. Higher Education, 51(3), 411-438. https://doi.org/10.1007/s10734-004-6413-6

Schultz, T. W. (1961). Investment in human capital. American Economic Review, 51(1), 1-17. 
Siphambe, H. K. (2000). Rates of return to education in Botswana. Economics of Education Review, 19(3), 291-300. https://doi.org/10.1016/So272-7757(99)00042-4

Soysal, O. A. (2000). Computer integrated experimentation in electrical engineering education over distance. https://peer.asee.org/computer-integrated-experimentation-in-electricalengineering-education-over-distance.pdf

Spence, M. (1973). Job market signaling. The Quarterly Journal of Economics, 87(3), 355-374. https://doi.org/10.2307/1882010

Stella, A., \& Gnanam, A. (2004). Quality assurance in distance education: The challenges to be addressed. Higher Education, 47(2), 143-160. https://doi.org/10.1023/B:HIGH.0000016420.17251.5c

Striegel, A. (2001). Distance education and its impact on computer engineering laboratories. https://www.researchgate.net/publication/2493514. http://doi.ieeecomputersociety.org/10.1109/FIE.2001.963707

Thomas, S. L. (2000). Deferred costs and economic returns to college major, quality, and performance. Research in Higher Education, 41(3), 281-313. https://doi.org/10.1023/A:1007003510102

Wang, G. G., \& Holton, E. F., III. (2005). Neoclassical and institutional economics as foundations for human resource development theory. Human Resource Development Review, 4(1), 86-108. https://doi.org/10.1177/1534484304273733

Wang, G. G., \& Sun, J. Y. (2009). Clarifying the boundaries of human resource development. Human Resource Development International, 12(1), 93-103. https://doi.org/10.1080/13678860802638875

Webber, D. (2014, October). Is the return to education the same for everybody? IZA World of Labor. https://wol.iza.org/uploads/articles/92/pdfs/is-the-return-to-education-the-same-foreverybody.pdf

Woodley, A., \& Simpson, C. (2001). Learning and earning: Measuring 'rates of return' among mature graduates from part-time distance courses. Higher Education Quarterly, 55(1), 28-41. https://doi.org/10.1111/1468-2273.00172

Wu, C. T., \& Tang, C. W. (2020). The impact of the expansion of higher education on the rate of return to higher education in Taiwan. In G. Fan \& T. S. Popkewitz (Eds.), Handbook of education policy studies (pp. 137-147). Springer. https://doi.org/10.1007/978-981-13-8343-4 7

Yang, C. H., Lin, C. H. A., \& Lin, C. R. (2011). Dynamics of rate of returns for postgraduate education in Taiwan: The impact of higher education expansion. Asia Pacific Education Review, 12(3), 359-371. https://doi.org/10.1007/s12564-010-9132-y 
Empirical Analysis of Return to Distance Higher Education in Different Disciplines

$\mathrm{Li}$ and Wang

Athabasca

University

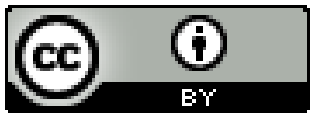

${ }^{1}$ Unless otherwise specified, China in the paper refers in particular to the mainland of China, not including Hong Kong, Macao and Taiwan. 